\title{
POLA LUKA PADA KORBAN MATI AKIBAT SENJATA API DI BAGIAN ILMU KEDOKTERAN FORENSIK MEDIKOLEGAL FK UNSRAT - RSUP PROF. Dr. R. D. KANDOUMANADO PERIODE JANUARI 2007-DESEMBER 2013
}

\author{
Rilano V. S. Umboh \\ Nola T. S. Mallo \\ Djemi Tomuka \\ ${ }^{1}$ Kandidat Skripsi Fakultas Kedokteran Universitas Sam Ratulangi Manado
${ }^{2}$ Bagian Ilmu Kedokteran Forensik \& Medikolegal Fakultas Kedokteran
Universitas Sam Ratulangi - RSUP Prof. dr. R. D. Kandou Manado
Email: umbohrilano@yahoo.com
}

\begin{abstract}
The aim of this study was to find out the patterns of gunshot wounds on dead victims. The study was conducted from October to December 2014 at Forensic and Medicolegal Department, Medical Faculty of Sam Ratulangi University - General Hospital of Prof. Dr. R.D. Kandou Manado. This was a retrospective descriptive study. The results showed that during the period of time from January 2007 to December 2013, there were two cases of gunshot wounds that met the criteria. The first case occured in July 2012 and the second case in November 2012. Both victims were males. The first victim was 25 years old and the second victim was 44 years old. The location of gunshot wound of the first victim was on his left chest while the second victim had gunshot wound on his left upper arm. The mechanisms of death of both victims were massive bleeding. Further studies with longer period of time that perform in other hospitals around Manado are suggested.
\end{abstract}

Keywords: patterns of wound, gunshot, dead victims

\begin{abstract}
Abstrak: Penelitian ini bertujuan untuk mengetahui pola luka pada korban mati akibat senjata api.Jenis penelitian bersifat deskriptif retrospektif dengan menggunakan data sekunder. Penelitian dilakukan di Bagian Ilmu Kedokteran Forensik Medikolegal FK Unsrat - RSUP Prof. dr. R.D. Kandou Manado selama periode Oktober 2014 sampai dengan Desember 2014.Hasil penelitian menunjukkan bahwa selama periode Januari 2007 sampai dengan Desember 2013 terdapat dua kasus luka tembak yang memenuhi kriteria. Kasus pertama terjadi pada Juli 2012 dan kasus kedua terjadi pada November 2012. Kedua korban berjenis kelamin laki-laki. Korban pertama berusia 25 tahun dan korban kedua berusia 44 tahun. Lokasi luka tembak korban pertama ada di bagian dada kiri sedangkan korban kedua ada di lengan atas kiri. Mekanisme kematian kedua korban adalah perdarahan masif. Disarankan penelitian lebih lanjut dengan periode yang diteliti lebih lama dan dilakukan di rumah sakit lainnya yang ada di sekitar Manado.
\end{abstract}

Kata kunci: pola luka, senjata api, korban mati

Penggunaan senjata api dalam tindak kekerasan dalam beberapa tahun terakhir ini mengalami peningkatan. Diperkirakan terdapat lebih dari 500.000 kasus luka tembak dalam setahun. Menurut WHO pada tahun 2001, jumlah tersebut mewakili seperempat dari total perkiraan 2,3 juta kematian akibat kekerasan. Dari 500.000 kasus luka tembak, 42\% merupakan kasus bunuh diri, 38\% merupakan kasus pembunuhan dan 20\% merupakan kasus perang dan konflik senjata. ${ }^{1,2}$ 
Luka tembak merupakan salah satu penyebab kematian di Amerika Serikat dan diperkirakan tiap tahun terdapat kurang lebih 70.000 korban luka tembak dengan 30.000 diantaranya mengalami kematian. ${ }^{1}$

Laporan dari Inggris dan Wales pada tahun 2001 angka kejadian luka tembak adalah 0,4/100.000 kasus dan ada laporan dari Kanada mengenai angka kejadian luka tembak yaitu 2,6/100.000 kasus. ${ }^{3}$ Laporan hak asasi manusia triwulan kedua tahun 1998 yang dikeluarkan oleh Lembaga Studi dan Advokasi Masyarakat pada triwulan kedua tercatat ada 102 warga negara yang menjadi korban kekerasan senjata api di Indonesia. ${ }^{4}$ Laporan mengenai angka kejadian dan pola luka akibat senjata api di Provinsi Sulawesi Utara khususnya di Kota Manado sampai saat ini belum ada. Berdasarkan beberapa hal tersebut, maka penulis merasa perlu untuk melakukan suatu penelitian yang bertujuan untuk mengetahui pola luka pada korban mati akibat senjata api.

\section{DEFINISI LUKA TEMBAK}

Luka tembak adalah luka yang disebabkan oleh penetrasi anak peluru ke dalam tubuh yang diproyeksikan lewat senjata api atau persentuhan dengan tubuh. Luka tembak dapat dibagi menjadi dua, yaitu luka tembak masuk dan luka tembak keluar. Luka tembak masuk terjadi apabila anak peluru masuk suatu objek dan tidak keluar lagi, sedangkan pada luka tembak keluar anak peluru menembus objek secara keseluruhan. Pada luka tembak biasanya juga ditemukan kerusakan pada pembuluh darah tulang, dan jaringan sekitar. Berdasarkan jarak luka tembak juga dapat dibagi menjadi empat kategori, yaitu kontak, jarak dekat, jarak sedang dan jarak jauh. ${ }^{5}$

\section{MEKANISME LUKA TEMBAK}

Terdapat tiga mekanisme tersering luka tembak yang dapat mengakibatkan kematian, yaitu: ${ }^{6}$

1. Kehilangan darah masif (perdarahan) adalah penyebab tersering kematian akibat senjata api adalah kehilangan darah yang banyak. Peluru menembus pembuluh darah arteri besar yang mengakibatkan pembuluh darah lubang, terjadi perdarahan. Jika sebuah peluru atau fragmennya masuk ke organ dalam seperti hati, cederanya itu sendiri tidak mengancam jiwa, tetapi perdarahan yang masif dapat membuat cedera itu mengancam jiwa.

2. Trauma juga dapat menyebabkan kematian. Saat sebuah peluru masuk menembus tubuh, peluru itu akan membuat lubang. Tergantung pada jenis peluru dan bagian tubuh mana yang terkena, pelurunya akan membuat luka utama. Jika pelurunya banyak dapat mengakibatkan luka dalam sekunder. Jika peluru masuk ke organ penting seperti, otak, sistem saraf, paru-paru, trauma tersebut dapat langsung menyebabkan kematian.

3. Infeksi merupakan penyebab kematian pada luka tembak. Penetrasi peluru akan

menghasilkan luka tembak. Peluru yang masuk dapat membawa kuman. Jika tidak diobati dengan baik apalagi luka yang dihasilkan luas dapat memudahkan terjadinya infeksi. Infeksi yang berat dapat terjadi syok sepsis, yang seringkali berakhir dengan kematian.

\section{DESKRIPSI LUKA TEMBAK}

Kepentingan medikolegal deskripsi yang adekuat dari luka senjata api bergantung pada besarnya potensi seorang korban meninggal. Jika korban masih hidup, deskripsi luka singkat dan tidak terlalu detail. Dokter mempunyai tanggung jawab yang utama untuk memberikan penatalaksanaan gawat darurat. Penggambaran luka secara detail akan dilakukan setelah semua kondisi gawat darurat dapat disingkirkan. Dokter sering merasa tidak mempunyai kewajiban untuk mendeskripsikan luka secara rinci oleh karena singkatnya waktu. $^{7}$

\section{KLASIFIKASI LUKA TEMBAK}

Luka tembak secara umum dibagi menjadi dua, yaitu luka tembak masuk dan 
luka tembak keluar. Luka tembak masuk juga dibagi dalam tiga, yaitu luka tembak

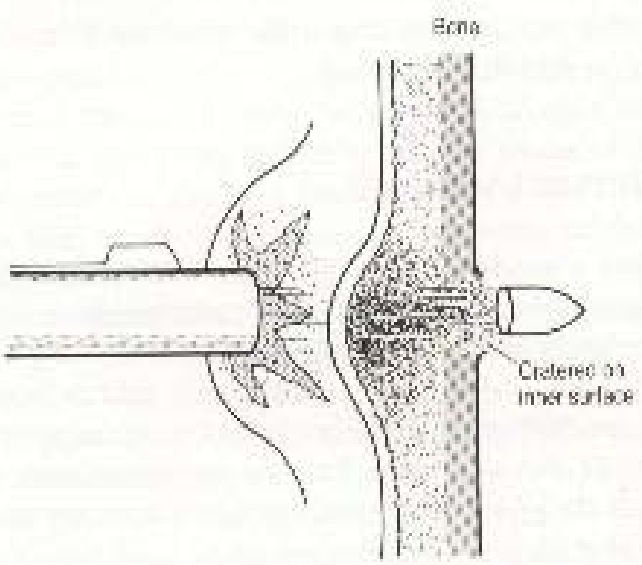

Gambar 1. Luka tembak tempel ${ }^{9}$ tempel (kontak), luka tembak jarak dekat dan luka tembak jarak jauh. ${ }^{8}$

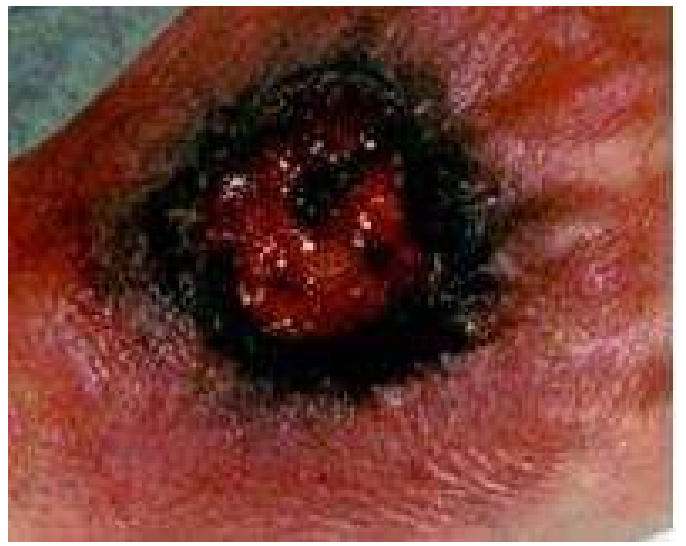

Gambar 2. Luka tembak jarak dekat ${ }^{10}$

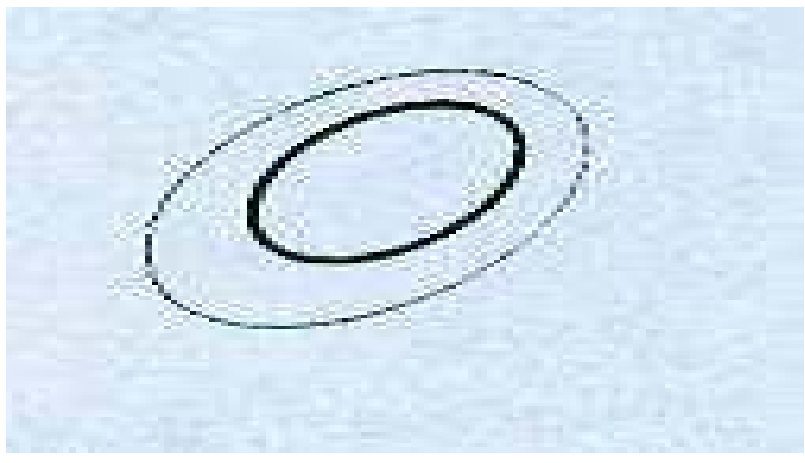

Gambar 3. Luka tembak jarak jauh ${ }^{9}$

\section{JENIS SENJATA API DAN AMUNISI}

Senjata api adalah suatu senjata yang dapat menyebabkan perlukaan atau kematian dimana anak peluru keluar dari senjata oleh karena terbakarnya mesiu. ${ }^{8}$ Senjata api adalah suatu senjata yang menggunakan tenaga hasil perledakan mesiu yang dapat melontarkan proyektil (anak peluru) yang berkecepatan tinggi melalui larasnya. ${ }^{7,11}$

Senjata api dapat dibedakan berdasarkan panjang laras dan alur laras. Berdasarkan panjang laras, senjata api terbagi dua, yaitu senjata api laras pendek dan senjata api laras panjang. Contoh senjata api laras pendek adalah revolver dan pistol sedangkan contoh senjata api laras panjang adalah senapan tabur dan senapan untuk menyerang. ${ }^{7,11}$ Berdasarkan alur laras, senjata api juga terbagi atas dua, yaitu senjata api laras beralur (rifled bore) dan senjata api laras tak beralur (smooth bore). ${ }^{8}$

Peluru mengandung lead $(\mathrm{Pb})$ dan sebagian metal dengan dikelilingi nikel, detonator berisi barium dan bismuth mercury. Shotgun dan senapan sama karena terbentuknya jumlah besar gas yang panas bertekanan tinggi. ${ }^{7,8}$ 




Gambar 4. Senjata api laras pendek ${ }^{9}$

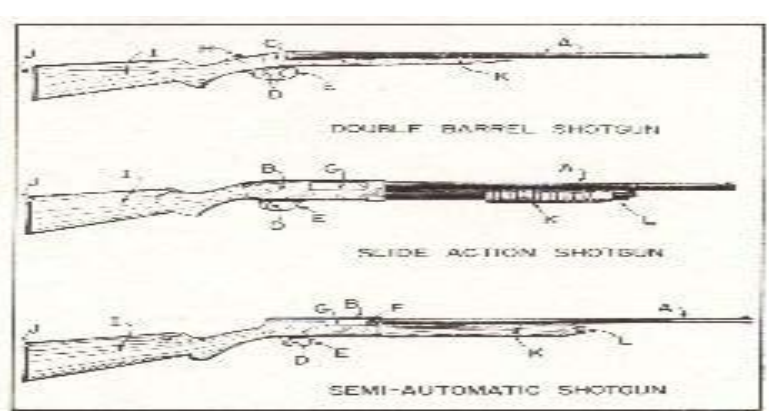

Gambar 5. Senjata api laras panjang ${ }^{9}$

\section{PEMERIKSAAN KHUSUS PADA LUKA TEMBAK}

Pemeriksaan terhadap luka tembak masuk sering dipersulit oleh adanya pengotoran oleh darah sehingga pemeriksaan tidak dapat dilakukan dengan baik akibat penafsiran atau kesimpulan mungkin sekali tidak tepat. Untuk menghadapi penyulit pada pemeriksaan tersebut dapat dilakukan sesuai prosedur. Luka tembak dibersihkan dengan hidrogen peroksida. Setelah 2-3 menit luka tersebut dicuci dengan air untuk membersihkan busa yang terjadi dan membersihkan darah. Dengan pemberian hidrogen peroksida tadi, luka tembak akan bersih dan tampak jelas sehingga deskripsi luka dapat dilakukan dengan akurat. Selain secara makroskopik, yaitu dengan karakteristik pada luka tembak masuk, tidak jarang diperlukan pemeriksaan khusus untuk menentukan secara pasti bahwa luka tersebut luka tembak masuk ini disebabkan oleh karena tidak selamanya luka tembak masuk memperlihatkan ciri-ciri yang jelas. Adapun pemeriksaan khusus yang dimaksud, yaitu: ${ }^{8}$

1. Pemeriksaan mikroskopik

2. Pemeriksaan kimiawi

3. Pemeriksaan dengan sinar $\mathrm{X}$

4. Pemeriksaan baju pada korban luka tembak

\section{METODE PENELITIAN}

Penelitian yang dilakukan bersifat deskriptif retrosepktif dengan menggunakan data sekunder. Penelitian ini dilakukan selama bulan Oktober 2014 sampai dengan Desember 2014 di Bagian
Ilmu Kedokteran Forensik Medikolegal FK Unsrat-RSUP Prof. dr. R. D. Kandou Manado. Objek penelitian dalam penelitian ialah surat keterangan Visum et Repertum yang ada di tempat penelitian. Surat keterangan Visum et Repertum yang diteliti yaitu selama periode Januari 2007 Desember 2013.

\section{HASIL PENELITIAN \\ Jumlah kasus sesuai kriteria}

Pada tabel 1 dapat dilihat jumlah kasus luka akibat senjata api pada korban mati selama periode Januari 2007 sampai Desember 2013 yang diperiksa menurut data Visum et Repertum (VeR) di Bagian Ilmu Kedokteran Forensik Medikolegal FK Unsrat - RSUP Prof. dr. R. D. Kandou Manado.

\section{BAHASAN}

Hasil penelitian ini (tabel 2) didapatkan dua kasus kematian akibat senjata api selama periode Januari 2007 sampai Desember 2013 di Bagian Ilmu Kedokteran Forensik Medikolegal FK Unsrat - RSUP Prof. dr. R. D. Kandou Manado. Sedikitnya kasus yang ditemukan pada penelitian ini tidak dapat menggambarkan jumlah kasus keseluruhan di Kota Manado apalagi di Propinsi Sulawesi Utara. Hal ini dapat terjadi banyak kasus lain yang tidak dibawa ke RSUP Prof. dr. R. D. Kandou Manado tetapi dibawa ke rumah sakit lain atau jumlah kasus kematian akibat senjata api memang hanya sedikit di Kota Manado. Mungkin penyebabnya adalah penggunaan senjata api di kalangan masyarakat yang 
masih kurang. Masyarakat Kota Manado masih cenderung melakukan kekerasan menggunakan benda yang lebih tradisional.

Data sampel pada penelitian ini diambil dari hasil dan temuan visum kedua korban. Visum et Repertum adalah keterangan yang dibuat oleh dokter atas permintaan penyidik yang berwenang mengenai hasil pemeriksaan medis terhadap manusia, baik hidup maupun mati. Visum et Repertum menguraikan segala sesuatu tentang hasil pemeriksaan medis. Pada surat permintaan harus jelas tertulis jenis pemeriksaan yang diminta, apakah hanya pemeriksan luar atau pemeriksaan dalam (autopsi). Adapun tujuan dari Visum et Repertum adalah untuk menentukan identitas korban, sebab kematian, pola luka, ada tidaknya penyakit alamiah atau pengaruh obat dan alkohol, dan memberikan kesimpulan dari hasil pemeriksaan forensik. ${ }^{5}$

Tabel 1. Jumlah kasus luka akibat senjata api pada korban mati selama periode Januari 2007 sampai Desember 2013 yang diperiksa menurut data Visum et Repertum (VeR) di Bagian Ilmu Kedokteran Forensik Medikolegal FK Unsrat - RSUP Prof. dr. R. D. Kandou Manado

\begin{tabular}{lc}
\hline Tahun & $\mathrm{n}(\%)$ \\
\hline 2007 & - \\
2008 & - \\
2009 & - \\
2010 & - \\
2011 & - \\
2012 & $2(100 \%)$ \\
2013 & - \\
\hline
\end{tabular}

\section{Karakteristik seluruh sampel}

Pada tabel 2 dapat dilihat karakteristik seluruh sampel berdasarkan jenis variabel.

Tabel 2. Karakteristik seluruh sampel

\begin{tabular}{lll}
\hline Jenis variabel & Korban pertama & Korban kedua \\
\hline Jenis kelamin & Laki-laki & Laki-laki \\
Umur(tahun) & 25 & 44 \\
Lokasi luka & Dada kiri & Lengan atas kiri \\
Mekanisme & Perdarahan & Perdarahan \\
kematian & & \\
\hline
\end{tabular}

Dari surat keterangan Visum et Repertum kedua korban dapat diperoleh identitas korban, umur, jenis kelamin, lokasi luka dan sebab kematian. Dua korban yang menjadi sampel penelitian adalah laki-laki. Jenis kelamin semua korban adalah lakilaki bukan suatu hal yang kebetulan. Hal ini mungkin dapat diakibatkan beberapa faktor. Secara teori bahwa laki-laki memiliki sex-determining region $Y$ (SRY), yang dapat memengaruhi tingkat agresifitasnya dalam merespon suatu hal atau dalam keadaan stres. ${ }^{12}$ Oleh karena itu, dapat dikatakan bahwa laki-laki cenderung lebih agresif daripada perempuan. Faktor tersebut dapat menjadikan laki-laki banyak memiliki konflik dengan orang lain dan membuat laki-laki rentan dalam penembakan.

Penelitan ini juga memperoleh alur luka penyebab kematian korban. Hasil yang kami dapatkan bahwa korban pertama didapatkan luka yang menembus kulit, jaringan bawah kulit, iga IV kiri menembus paru kiri bagian atas, pangkal paru, paru kiri bagian bawah, pembuluh nadi utama, 
tulang belakang dan berakhir di sum-sum tulang belakang dengan panjang alur 20 cm. Temuan visum pada korban kedua menunjukkan luka tembak di lengan atas kiri yang menembus kulit, jaringan bawah kulit, otot, tulang selangka kiri, masuk ke rongga dada dan paru bagian atas, jaringan antar iga IV kanan dan masuk ke jaringan otot. Alur luka ditemukan dari kiri atas depan ke kanan bawah belakang, sepanjang $38 \mathrm{~cm}$. Penelitian ini juga menunjukkan sebab kematian dari korban. Sebab kematian korban pertama ialah luka tembak pada dada kiri yang merusak paru dan melubangi pembuluh nadi utama. Luka tembak pada daerah lengan atas kiri yang masuk ke rongga dada dan merusak paru kanan sehingga terjadi perdarahan disimpulkan sebagai penyebab kematian pada korban kedua. Mekanisme kematian dari kedua kasus pada penelitian ini dapat disimpulkan adalah perdarahan yang masif. Pada kasus pertama korban kehilangan darah karena terjadi lubang pada pembuluh nadi utama. Secara teori bahwa pada kondisi terjadi robekan atau lubang pembuluh nadi utama, sangat cepat dapat terjadi syok hemorhagik atau syok perdarahan bahkan dapat menyebabkan kematian sehingga kondisi ini membutuhkan penanganan yang segera. Temuan pada korban kedua juga mengalami kehilangan darah yang banyak karena kerusakan paru kanan. Kemungkinan pada korban kedua mengalami hematotoraks, dimana luka tembak masuk ke dalam dada sehingga menyebabkan adanya darah dalam rongga pleura. Trauma pada toraks yang terjadi dapat menyebabkan gagal ventilasi (keluar masuknya udara), kegagalan pertukaran gas pada tingkat alveolar (organ kecil pada paru yang mirip kantung), dan kegagalan sirkulasi karena perubahan hemodinamik (sirkulasi darah). Trauma pada dada juga dapat menyebabkan kematian. ${ }^{13}$

\section{SIMPULAN}

Berdasarkan hasil penelitian yang telah dilakukan, maka dapat disimpulkan sebagai berikut:
1. Ditemukan dua kasus luka akibat senjata api yang menyebabkan kematian di Bagian Ilmu Kedokteran Forensik Medikolegal FK Unsrat - RSUP Prof.dr. R. D. Kandou Manado selama periode Januari 2007 sampai Desember 2013.

2. Ditemukan kedua kasus tersebut di atas terjadi pada tahun 2012, yaitu pada bulan Juli dan November.

3. Ditemukan kedua korban adalah laki-laki. Korban pertama berumur 25 tahun sedangkan korban kedua berumur 44 tahun.

4. Ditemukan lokasi luka korban pertama pada dada kiri sedangkan lokasi luka korban kedua pada lengan atas kiri.

5. Ditemukan sebab kematian kedua korban adalah perdarahan masif.

\section{SARAN}

Berdasarkan kesimpulan tersebut, beberapa hal dapat disarankan yaitu:

1. Perlu penelitian lebih lanjut dengan periode yang diteliti lebih lama.

2. Perlu penelitian lebih lanjut di rumah sakit lainnya yang ada di sekitar Kota Manado.

3. Perlu penelitian lebih lanjut dengan membandingkan kasus luka akibat senjata api yang terdata di kantor kepolisian.

\section{DAFTAR PUSTAKA}

1. Cook P, Lawrence B, Ludwig J. The medical cost of gunshot injuries in the United States. JAMA; 1999. p. 282, 447-54.

2. Small arms and global health. Geneva: World Health Organization; 2011.

3. Shkrum MJ, Ramsay DA. Forensic science and medicine: Forensic pathology of trauma. New Jersey: Human Press Inc; 2007.

4. Laporan hak asasi manusia [Internet]. 1998 [cited 2014 Sep 05].Available from: http:/www.elsam.or.id/pdf/pap er/1998/Tri2_98.pdf

5. Idries AM. Pedoman ilmu kedokteran forensik. 1st ed. Jakarta: Binarupa 
Aksara; 1997.

6. Ordog GJ, Balasubramaniam S, Wasserberger J. Outpatient management of 357 gunshot wounds to the chest. J Trauma; 1983. p. 832-5.

7. Hueske E.Firearms and tool mark the forensic laboratory handbooks, practice and resource. 2006.

8. Tiarasari P, Qinta B, Saputro ED, Faulinza E, Mustika RR, Monalisa R.Luka tembak [Internet].2011 [cited 2014 Sep 08]. Available from: www.academia.edu/4200262/7612528 9_luka_tembak

9. Di Maio, VJM.Gunshot wounds practical aspects of firearms, ballistics, and forensic techniques. 2nd ed. New York: CRC; 1999.

10.Indah PS, Lely, Irene, Elena, Luh S. Gunshot wound [Internet]. 2010 [cited 2014 Sep 10]. Available from:http://www.freewebs.com/ gunshot_wound/luka tembak pada tulang.html

11.Algozi AM. Luka tembak [Internet]. 2011 [cited 2014 Sep 18]. Available from: http://www.fk.uwks.ac.id/elib/ Arsip/Departemen/Forensik/luka\%20te mbak.pdf

12.Fischer AH. Gender and emotions. Cambridge: Cambridge Universal Press; 2000.

13.Varghese TK. Chest trauma. In: Mullohan et al. Greenfield's Surgery. USA: Lippincot Wilkins; $\quad$ 2011. p. 370. 